\title{
Toward Personalized Cell Therapies by Using Stem Cells: Seven Relevant Topics for Safety and Success in Stem Cell Therapy
}

\author{
Fernando de Sá Silva, ${ }^{1}$ Paula Nascimento Almeida, ${ }^{2}$ João Vitor Paes Rettore, ${ }^{2}$ \\ Claudinéia Pereira Maranduba, ${ }^{2}$ Camila Maurmann de Souza, ${ }^{2}$ \\ Gustavo Torres de Souza, ${ }^{2}$ Rafaella de Souza Salomão Zanette, ${ }^{2}$ \\ Sueli Patricia Harumi Miyagi, ${ }^{3}$ Marcelo de Oliveira Santos, ${ }^{2}$ \\ Márcia Martins Marques, ${ }^{3}$ and Carlos Magno da Costa Maranduba ${ }^{2}$ \\ ${ }^{1}$ Post-Graduation Program in Biotechnology, Institute of Biomedical Sciences, University of São Paulo, São Paulo, SP, Brazil \\ ${ }^{2}$ Laboratory of Genetics, Department of Biology, Institute of Biological Sciences, Federal University of Juiz de Fora, \\ Juiz de Fora 36036-900, MG, Brazil \\ ${ }^{3}$ Restorative Dentistry Department, School of Dentistry, University of São Paulo, São Paulo, SP, Brazil
}

Correspondence should be addressed to Carlos Magno da Costa Maranduba, carlos.maranduba@ufjf.edu.br

Received 16 June 2012; Accepted 18 October 2012

Academic Editor: Herman S. Cheung

Copyright ( 92012 Fernando de Sá Silva et al. This is an open access article distributed under the Creative Commons Attribution License, which permits unrestricted use, distribution, and reproduction in any medium, provided the original work is properly cited.

\begin{abstract}
Stem cells, both embryonic and adult, due to the potential for application in tissue regeneration have been the target of interest to the world scientific community. In fact, stem cells can be considered revolutionary in the field of medicine, especially in the treatment of a wide range of human diseases. However, caution is needed in the clinical application of such cells and this is an issue that demands more studies. This paper will discuss some controversial issues of importance for achieving cell therapy safety and success. Particularly, the following aspects of stem cell biology will be presented: methods for stem cells culture, teratogenic or tumorigenic potential, cellular dose, proliferation, senescence, karyotyping, and immunosuppressive activity.
\end{abstract}

\section{Introduction}

The study of the stem cells potential has stimulated the onset of new areas, as the regenerative medicine and tissue bioengineering. Cell-based therapies to treat human diseases have become a clinical reality in the light of the advances in research with adult stem cells and embryonic stem cells, the two major divisions of stem cells. Recent works have shown that it is already possible to reprogram somatic cells into ones with similar characteristics to ESCs, being referred to as induced pluripotent stem cells (iPSCs). These cells are strong candidates to be applied in cellular therapy, requiring even more studies to master this new technology.

PubMed searches for publications with the exact terminology "stem cell therapy" indicate a strong growth in the number of publications in this area over the last 19 years, shown in Figure 1. In spite of the obvious importance of this issue, only few manuscripts appeared before 2000 years.
Aiming for a personalized cell therapy, some criteria or parameters must be observed. This paper will discuss some controversial issues of importance for achieving cell therapy safety and success. Particularly, the following aspects of stem cell biology will be presented: methods for stem cells culture, teratogenic or tumorigenic potential, cellular dose, proliferation, senescence, karyotyping, and immunosuppressive activity.

\section{Cell Culture Free of Animal Components}

Methods of cell cultivation have been fundamental to physiological, biological, and pharmacological assessments at cellular and tissue levels [1], as well as to molecular studies. Besides enabling the production of biological components of human interest, such as vaccines and hormones, cell cultures help in the advancement of stem cell research by 


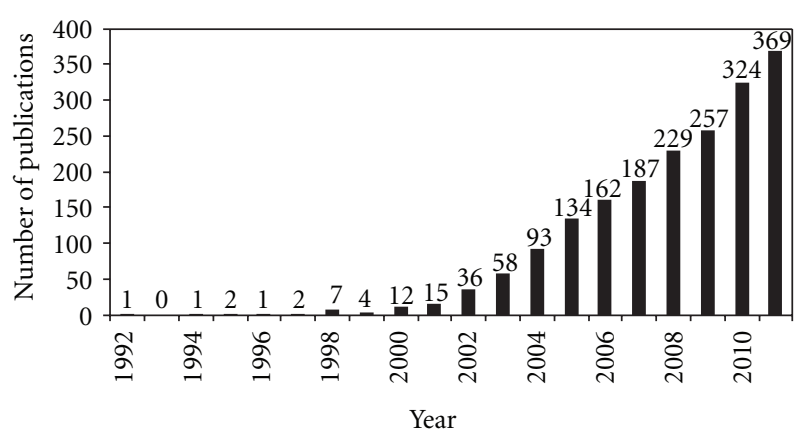

Figure 1: Published articles from 1992 to 2011. The information was retrieved from PubMed indexed articles using the exact terminology "stem cell therapy."

allowing the improvement of the stem cells for cellular therapy. The cultivation conventional system of mammalian cells is performed in an incubator at $37^{\circ} \mathrm{C}\left(5 \% \mathrm{CO}_{2}\right.$ and $95 \%$ $\mathrm{O}_{2}$ ). The composition of the culture medium is critical to the success of cell culture and the maintenance of cells for long periods in vitro, often requiring to be supplemented with other factors, such as serum. The most commonly used serum is fetal bovine serum (SFB) which is composed of a mixture of several substances in undefined concentrations as hormones, growth factors, vitamins, and other unknown substances [1].

The use of serum in culture media in research is associated with several problems such as limited availability of good fetal bovine serum suppliers, batch-to-batch variation causing inconsistency in both cell growth pattern and products formation and the risk of viral, mycoplasmal, and prions contamination, and interfering with the effect of hormones or growth factors upon studying their interaction with cells [2-4]. Due to the possible contamination of stem cells with bovine infectious agents and the concern of transmission of these agents to patients, plus the possibility of cultured cells to incorporate animal proteins that can provoke allergic reactions in humans [4], there is a growing concern and a consensus that research has to be done in order to establish new supplements and cultivation conditions for cell therapy, avoiding the use of animal-origin reagents in cell culture.

There are more than 100 serum-free culture medium formulations [5] with 4 basic types of culture medium [1]: (i) serum-free medium; containing small fractions of protein either from animal origin or from plant extracts which characterize it as a medium chemically undefined; (ii) protein-free medium; it has fractions of peptides (hydrolysed proteins) and is also considered to be a chemically undefined medium; (iii) animal- and human-derived components-free medium; it is not considered to be chemically defined, since it may contain bacteria, yeast hydrolysates, and plant extracts; (iv) chemically defined medium; it does not have protein, hydrolysed or any component of unknown composition. Hormones, animal or plant growth factors, as well as highly purified recombinant products may be supplemented in the culture medium.
Many research groups have been struggling to achieve the appropriate culture medium for cell therapy; however, many searches need to be performed to achieve this purpose.

\section{Teratogenic or Tumorigenic Propriety of Stem Cells}

The stem cells can be classified as embryonic (ESCs) and adult stem cells (ASCs). ESCs research reveals their enormous potential for differentiation and ability to originate almost all tissues of our body. The establishment of ESCs lines is problematic, since it involves ethical issues in relation to the destruction of embryos. According to the literature, there are several reports of ESCs transplants performed on animals, which resulted in the formation of teratomas on the recipient organism [6-14], which is undesirable for cellular therapy. Particularly, teratomas have been formed by hESC transplantation into the testis [15-17], kidney capsule [18], liver [19], hind leg muscle [20-23], and into the subcutaneous space $[19,24]$.

Numerous published reports have examined the potential of differentiated cell types derived from mouse and human ESCs to repair nonhuman target organs in intact animals [25-33]. Recent studies, however, have yielded both encouragement and caution, with restoration of function evident to some degree in many cases, but coexisting in others with the troubling finding that the grafts contained evidence of cancerous growth [8, 14, 34-38].

Kahan et al. [39] showed that the selection of embryonic stem cells presenting the markup SSEA $1^{-}$SSEA3 $^{-}{ }^{-}$PCAM $^{+}$, both mouse and human, resulted in eliminating the tumorigenic potential from differentiated ESC populations. Sorted cells do not form teratomas after transplantation into immunodeficient mice, but showed gene and protein expression profiles that are indicative of definitive endoderm cells. Sorted cells could be subsequently expanded in vitro and further differentiated to express key pancreas specification proteins. In vivo transplantation of sorted cells resulted in small, benign tissues that uniformly express PDX1. It represents one of transcripts expressed during gastrulation or early periods of endoderm development.

Adult stem cells have generated great interest among the scientific community devoid of their potential therapeutic applications for unmet medical needs. According to some studies, in addition to ESCs, some adult stem cells also form tumors when reintroduced into the organism. Recently, it was reported a case of a child with ataxia telangiectasia that developed multifocal brain and spinal cord tumors 4 years after treatment with human neural stem cells originating from at least two donors, even though the cells were relatively freshly derived from chromosomally normal fetuses [40]. Among ASCs, we highlight the hematopoietic stem cells (HSCs) and mesenchymal stem cells (MSCs) as those most well studied and reported in the scientific literature.

Obtaining the HSCs from bone marrow is an invasive and painful process for the patient. The HSCs are more restricted, as they have the capacity of proliferation and differentiation, resulting only in cells of the myeloid and 
lymphoid lineages. The transplant with HSCs must also be careful because it can result in graft-versus-host disease (GVHD) [41, 42]. This is a systemic syndrome that occurs in patients that receive immunocompetent lymphocytes. The pathophysiology involves an immune reaction between transplanted lymphocytes and development of an immune attack of the $T$ cells from the donor to the host's cell, which differ from the former by histocompatibility antigens. It is, therefore, a primary complication of allogeneic bone marrow transplantation $[41,42]$. The first three months after transplantation of HSCs can be marked by a greater number of complications due to direct toxicity of the conditioning, coupled with prolonged period of aplasia, infections, and acute GVHD. After this period and in the months ahead, complications are less frequent but also occur, as a result of chronic GVHD, with late damages to several organs and hematopoietic system [43]. For these reasons, HSCs should also be used with caution. In accordance with the literature, the HSCs obtained by ESCs differentiation can result in teratomas when reintroduced into the body. Its use in cell therapy should ensure that the transplanted cells will be free of residual teratogenic cells [44-47].

Besides the HSCs, there is another cell type present in the bone marrow which has great potential for cell therapy, the mesenchymal stem cells (MSCs). MSCs have been identified from various tissues in the past decade, including bone marrow, adipose tissue, umbilical cord, and dental pulp. The International Society for Cellular Therapy has recommended the following minimum criteria for defining multipotent human MSCs [48, 49]: (i) adherence to plastic under standard culture conditions; (ii) positive for expression of $\mathrm{CD} 105, \mathrm{CD} 73$, and CD90 and negative for expression of the hematopoietic cell surface markers CD34, CD45, CD11a, CD19 or CD79a, CD14 or CD11b, and histocompatibility locus antigen (HLA)-DR; (iii) under a specific stimulus, differentiation into osteocytes, adipocytes, and chondrocytes in vitro. To date, human bone marrow represents the major source of MSCs [50-54], and MSCs have potential to be expanded and cryopreserved for future use as an off-the-shelf therapy [55]. Currently, autologous MSCs derived from bone marrow have been applied for cell-based therapies, including the treatment of osteogenesis imperfecta, intracoronary transplantation in patients with acute myocardial infarction, and support of haematopoiesis [50, 51, 53, 54, 56]. Studies in mice show that MSCs are also involved in carcinogenesis. Houghton et al. [57] showed that chronic infection of C57BL/6 mice with Helicobacter, a known carcinogen, repopulated the stomach with bone-marrow-derived cells. It was observed that these cells progressed through metaplasia and dysplasia to intraepithelial cancer. These findings have broad implications for the multistep model of cancer progression, as they suggest that epithelial cancers can be originated from bone-marrow-derived sources [57]. Thus, a study of carcinogenic potential sources of many adults MSCs is prudent.

The reprogramming of somatic cells was a major advance in order to avoid ethical problems related to the destruction of the embryo, and this methodology has helped understand even more about pluripotency. There is an effort to improve the technique, since many use retroviral or lentiviral vectors for expression of genes related to embryonic transcription factors (NANOG, OCT4, and KFL4) besides c-Myc. The reprogrammed cells exhibit characteristics similar to embryonic stem cells, the ability to differentiate into many cell types, but there are also several reports of teratoma formation [58-60].

\section{Appropriate Cellular Dose to Be Transplanted}

One of the major issues to be addressed is the cell dose to be transplanted into a patient, which would provide successful treatment. As well as medicines, there must be a correlation between cell number and the body weight of the patient. According to the literature, there is no consensus among researchers about the cell dose required.

Currently, the most used cells in cell therapy are hematopoietic stem cells present in umbilical cord blood (CB) and bone marrow and, in some cases, in the peripheral blood. Human umbilical cord blood has long been recognized as a rich source of primitive and committed hematopoietic progenitors. In addition, the general availability and the ease of procurement make cord blood a very attractive alternative source of transplantable hematopoietic tissue [61]. HSCs are contained within a population of mononuclear CD34+ antigen-expressing cells, which typically represent less than $1 \%$ of the total leukocytes in CB [62]. Research have suggested that, on the basis of the number of progenitor cells present in umbilical cord blood, it needs to be transplanted with restriction on children and some adults weighing less than $40 \mathrm{~kg}$ [63-65].

Jaime-Pérez et al. [66] analyzed $794 \mathrm{CB}$ units in which the amount of $\mathrm{CD} 34^{+}$cells was determined by flow cytometry. Although there are not accepted universal guidelines, most Cord Blood Banks use the combination of product weight (volume) and total nucleated cell (TNC) count as the main selection factors for cryopreservation, requiring a TNC content from $6-10 \times 10^{8}$ for storage [67] and a minimal volume between 40 and $60 \mathrm{~mL}$ [68-70]. The study showed that the amount of TNC is the best parameter that correlates with the contents of $\mathrm{CD} 34+$ cells, being in agreement with previous reports [71-73] and that all CB units having a TNC count of $8 \times 10^{8}$ or more had the required CD34+ cell dose for patients weighing $10 \mathrm{~kg}$ or less.

Even in the face of such an impasse, the use of cord blood has been extended to include adults, allowing better definitions of cell dose limitations and thresholds [74-79]. The results of these transplants have helped to define a requirement for a minimum cell dose from $3 \times 10^{7}$ to $3.5 \times$ $10^{7}$ nucleated cells/kg in order to obtain acceptable clinical outcomes [80], and specifically, the CD34+ cell content has been shown to influence engraftment and survival after unrelated UCB transplantation, better predicting the hematopoietic potential of a $\mathrm{CB}$ unit was obtained after infused with $1.7 \times 10^{5} \mathrm{CD} 34+$ cells per kilogram of the recipient's body weight the threshold dose than nucleated cell content [81].

Nucleated cells can also be obtained from the bone marrow and peripheral blood. Hernigou et al. [82], aiming 
for autologous transplantation, calculated the number of medullary nuclear cells per $\mathrm{kg}$ of marrow using a formula that takes into account blood dilution. In each milliliter of aspirate, it was estimated that medullary cells were represented by the difference between the nuclear cell count in the aspirate and that in peripheral blood, which is assessed during general anesthesia. The number of nuclear cells of presumed medullary origin per $\mathrm{kg}$ is expressed as follows: $N\left(10^{8} / \mathrm{kg}\right)=(V \times \mathrm{NP})-(V-100) \times \mathrm{NS} / \mathrm{P}$, where $V$ is total volume of aspirate in $\mathrm{mL}$, including the harvesting medium; NP is nuclear cell count per milliliter in the collection bag which leaves the operating room, including the harvesting medium; $V-100$ is the exact volume of aspirate, after subtraction of the $100 \mathrm{~mL}$ of harvesting medium; NS is the nuclear cell count per milliliter of peripheral blood drawn during general anesthesia; $P$ is patient's weight in kilograms. Thus, for these parameters researchers suggest a total final volume of $300 \mathrm{~mL}$ containing $14 \times 10^{6}$ nuclear cells per milliliter, obtained from a $70 \mathrm{~kg}$ adult with a leucocyte count of $4 \times 10^{6}$ per milliliter as determined under general anesthesia, it may be estimated that the medullary nuclear cell count is $5 \times 10^{7}$ per kilograms, for a total of $0.35 \times 10^{10}$ nuclear cells [82]. In case of allogeneic transplants, it is recommended to be obtained a number of nucleated cells greater than $2 \times 10^{8} / \mathrm{Kg}$. This way, when the weight of the donor is similar to the weight of the receptor, this value is obtainable by the aspiration of nearly $10 \mathrm{~mL} / \mathrm{kg}$ of the weight of the donor, by volume of aspired bone marrow [83].

In peripheral blood, under normal conditions, there is a small number of stem cells (CD34+). Therefore, the use of this route to obtain stem cells for medullar transplant requires the prior mobilization of these cells from the bone marrow to the blood [84]. This mobilization is done by the administration of recombinant hematopoietic growth factor or colony-stimulating factor (CSF) to obtain a sufficient concentration of blood $\mathrm{CD} 34^{+}$cells in the blood and ensure the success of the transplantation $[84,85]$. The optimal number of CD34+ cells for allogeneic transplantation is not well established and it is usually done with 4 to $6 \times 10^{6} \mathrm{CD} 34+$ cells $/ \mathrm{kg}$ of the receiver's weight [86-89]. In autologous transplant, the recommendation is that the number of cells must be greater than $2 \times 10^{6} \mathrm{CD} 34+$ cells $/ \mathrm{kg}$ of the patient's weight [90].

\section{Proliferation, Senescence, and Karyotype}

The embryonic and adult stem cells may undergo symmetric cell divisions to self-renew or undergo terminal differentiation, or they may undergo asymmetric cell divisions to generate differentiated progeny as well as maintain a pool of stem cells. A dynamic balance between proliferation, survival, and differentiation signals ensures that an appropriate equilibrium between stem cells, precursor cells, and differentiated cells is maintained throughout development and adult life [91].

This renewal capacity is not a perfect process and the "daughter's cells" gradually lose the ability to proliferate, partly due to a gradual erosion of telomeres in each cell division. This phenomenon can be observed both in vivo and in vitro [92-95]. Telomeres are structures present at the end of eukaryotic chromosomes that protect chromosomes from degradation, fusion, and recombination. In mammalian cells, they consist of hexanucleotide (TTAGGG) repeats and several associated protein components. In the absence of compensatory mechanisms, dividing cells undergo gradual telomere reduction. When telomeres reach a critical degree of shortening, cells recognize this as DNA damage and initiate proapoptotic programs or enter senescence [96].

In vivo, as the body ages, the stock of stem cells in our body decreases, being perhaps the explanation for the failure of some organs repair during ageing. In studies with bone marrow conducted in over 1,000 patients [97-104], it was noted that the bone marrow cellularity: (a) decreases with increasing age and (b) decreases with the prevalence of connective tissue progenitors with increasing age in women. The total number of progenitors represents the product of the nucleated cells and the prevalence of progenitors in the aspirate plus a decline in the number of nucleated cells can be corrected by an increase of the volume aspirated.

Proliferation/expansion potential of hMSCs is affected by the in vitro culture conditions, which results in changing of cell/culture morphology. An interesting example is that under established in vitro conditions, hMSCs grow as a monolayer, but when cultured in hypoxic atmosphere, a condition found in many tumors in vivo, they continue to proliferate and the cell density increases, showing a 30fold higher expansion rate [105]. The investigation of the proliferative potential of cells in vitro is necessary due to the possibility of tumor formation by some adult stem cells and especially embryonic stem cells. This process is a result of the loss of normal cellular control and is an initial aspect of cancerous tumor formation. It is important to note that most tumors arise from dividing populations of stem or precursor cells. Indeed, in the hematopoietic system each stage of stem cell to blast cell to be differentiated cell is associated with a leukemia or lymphoma [106]. The relative infrequency of transformation, however, suggests that the ability to selfrenewing, surviving, proliferation, differentiation or transformation are closely regulated features. Thus, it commonly believed that the overall stem cell status in any self-renewing tissue is a dynamic balance between cell intrinsic and cell extrinsic factors. Furthermore, abnormalities in any of these stages will alter normal development or will affect cellular response to the normal aging process [91].

The cell proliferation also influences the karyotype of stem cells. In karyotypes of human mesenchymal stem cells (hMSCs), at least 30\% of senescent hMSCs display trisomy of chromosome 8 [107]. hMSCs generally become polyploid (mainly tetraploid) at passage 20 becoming aneuploid afterwards [108]. During senescence, hMSCs deregulated genes were mainly found at the short arm chromosome region 4 q22-q23, which inserted into immortal cells caused loss of proliferation. Senescence is also associated with upregulation of microRNAs, namely, hsa-mir-371, hsa-mir- 369-5P, hsamir-29c, hsa-mir-499, and hsa-let-7f, which causes a change in the methylation pattern [109]. Study with dental pulp stem cells revealed that about $70 \%$ of the cells exhibited 
karyotypic abnormalities including polyploidy, aneuploidy, and ring chromosomes. The heterogeneous spectrum of abnormalities indicated a high frequency of chromosomal mutations that continuously arise upon extended culture. These findings emphasize the need for the careful analysis of the cytogenetic stability of cultured hDSCs before they can be used in clinical therapies. With respect to therapy application, special attention should be given to hMSC epigenetic changes and the appearance of senescence that could result in genomic abnormalities, during culture.

Miura et al. [110] demonstrated that murine bonemarrow-derived mesenchymal stem cells (BMMSCs), after numerous passages, obtained unlimited population doublings and proceeded to a malignant transformation state, resulting in fibrosarcoma formation in vivo. Transformed BMMSCs colonized to multiple organs when delivered systemically through the tail vein. Fibrosarcoma cells formed by transformed BMMSCs contained cancer progenitors, which were capable of generating colony clusters in vitro and fibrosarcoma in vivo by the second administration. The mechanism by which BMMSCs transformed to malignant cells was associated with accumulated chromosomal abnormalities, gradual elevation in telomerase activity, and increased c-myc expression [110]. Although aneuploidy has long been associated with cancer, it has recently been observed in cultured pluripotent and neuronal stem cells as well as normal neuronal progenitors and primary cells from blastocysts, showing that the tendency to generate aneuploid cells may also be a normal feature of regenerative systems [110-112].

Cell transformation (spontaneous or artificial) is the process, initiated by at least 2 genetic events (mutations), by which cells gain immortality. First studies of spontaneous transformation claimed that unlike hMSCs, only murine MSCs can spontaneously transform in culture [113]. It was concluded that in vitro BM-hMSC expansion and their use in therapy is completely safe. But in parallel, Rubio et al. [107] demonstrated that after 4 to 5 months of in vitro culture, $50 \%$ of the postsenescent adipose tissue-derived mesenchymal stem cell (AThMSC) clones can escape the proliferation crisis, resume proliferation, lose contact inhibition, and become tumor-like transformed mesenchymal stem cells. It was argued nonetheless that the susceptibility to malignant transformation is dependent on hMSC origin, and that AThMSCs derived from poor fat tissue stem cell are more prone to transformation than BM hMSCs derived from stem cell-rich BM [114]. This argument was banned when BMhMSC clones were shown to spontaneously transform as well [115]. A 2-stage model of spontaneous transformation was proposed, according to which a senescence crisis with proliferation arrest always precedes the resumption of proliferation that occurs when hMSCs undergo spontaneous transformation [116]. This model was widely accepted and challenged only by Wang et al., who argued that spontaneous transformation may already occur as early as at hMSC isolation [117]. Spontaneously transformed hMSCs (transformed mesenchymal stem cells) are morphologically distinct from early passage hMSCs and senescent hMSCs
[107]. Spontaneous transformation is accompanied by distinct transcriptomic changes. Cells bypass the senescence crisis and transform by upregulation of c-myc expression, repression of p16 levels, acquisition of telomerase activity, Ink4a/Arf locus deletion, and $\mathrm{Rb}$ hyperphosphorilation [116]. In additional experiments the same authors were unable to confirm the in vitro hMSC transformation, since after a senescent phase, the hMSC culture became exhausted and the in vitro hMSC spontaneous transformation they described was an artifact due to cross-contamination with HT1080 cell line [118].

The biggest challenge in the use of stem cells in cellular therapy is the ability to maintain genetic integrity during long-term cultivation, as well as their ability to differentiate. By successive passages in vitro, the karyotype needs to be numerically and structurally intact, conferring genomic stability to the cells that are going to be used in cellular therapy. Cultured human adult stem cells are particularly susceptible to the acquisition of chromosomal anomalies because they require significant cell expansion [119-122].

\section{Immunosuppressive Activity}

Recently, scientists have been discussing the contribution that stem cells offer which leads to functional improvement of organ and body structures observed in experiments in vivo. Among the topics discussed, this contribution would come from tissue regeneration, cell fusion, and new blood vessels formation. Lately, the observation of the rapid postoperative recovery and rapid reestablishment of inflammatory condition caught the attention of scientists and led to deepening in the study of the fourth restorative of stem cells characteristic, the immunomodulator aspect, taken within cell-cell contact and paracrine contexts.

Many reports have shown MSCs to display low immunogenicity and profound immunomodulatory and antiinflammatory capabilities in vitro [123-125]. Furthermore, MSCs have been used to treat several animal and patient diseases, including graft-versus-host disease [126], rheumatoid arthritis [127, 128], autoimmune encephalomyelitis [129, 130], and systemic lupus erythematosus [131]. Apart from bone-marrow-derived MSCs, MSCs from dental tissues, that is, periodontal ligament stem cell $[132,133]$, stem cells from apical papilla, and gingiva-derived MSCs [134] also have been demonstrated to have immunomodulatory effects while inhibiting the proliferation and function of $\mathrm{T}$ lymphocytes.

Among the major works, there are those which seek to understand the mechanism by which stem cells immunomodulate investigating the interaction of these cells with specific cells and isolated from the immune system. Bartholomew et al. [135] demonstrated that the MSCs isolated from baboon suppressed the proliferation of lymphocytes in a mixed lymphocyte culture (MLC) stimulated with ConA, and this suppression was dose-dependent. In human MSCs (hMSCs), the same was observed by Aggarwal and Pittenger [136]; in PHA-induced proliferation T cells, the inhibition was $50 \%$ to $60 \%$. Rasmusson et al. [137] showed that the hMSCs inhibited the lyses promoted by cytotoxic 
$\mathrm{T}$ lymphocytes and that these cells escaped from the lyses promoted by NK cells more efficiently than K562 lymphoma cells. When cocultivated with B cells, the MSCs did not inhibit, but neither promoted the B-cells proliferation [138].

The MSCs tend to alter soluble factors decreasing proinflammatory factors and increasing anti-inflammatory ones. Aggarwal and Pittenger [136] conducted a series of experiments with different immune system cells. Dendritic cells (DCs) type 1 cocultured with hMSCs decreased levels of lipopolysaccharide (LPS)-induced TNF- $\alpha$; DCs type 2 cocultured with hMSC increased levels of IL-10 after LPS stimulus. The same results were observed with $\mathrm{TH} 1$ and $\mathrm{TH} 2$ cells. TH1 effector cells in the presence of hMSCs decrease in IFN- $\gamma$; TH 2 in the presence of hMSCs increase IL-4 levels. Finally, hMSCs were cocultured with IL-2-stimulated NK cells, that resulted in a decrease in IFN- $\gamma$. The production of immunoglobulins is also affected in the presence of MSCs. It has been seen that the MSCs in contact with spleen mononuclear cells (MNCs) stimulated with LPS reduced the IgG production, and that this effect is LPS dose-dependent. With a strong LPS stimulus, the MSCs have led to a reduced production of IgG, but with a low stimulus, they have led to an increase in IgG production. With enriched B cells, there was an increase in IgG production when grown with LPS and this increased even more in the presence of MSCs. While these cocultures did not influence the levels of IL-2, they raised the levels of IL-6, in the presence or absence of LPS, an important interleukin for differentiation and production of immunoglobulin [138]. Other factors secreted in cultures with hMSCs, in addition to the IL-6, were observed such as IL-8, PGE2, and vascular endothelial growth factor (VEGF) [136].

Then, the question whether there is a molecule that can have a central influence on the whole process of immunomodulation performed by stem cells remains. Aggarwal and Pittenger [136] conducted an investigation of the involvement of PGE2 in coculture with human peripheral blood mononuclear cells (PBMCs). Using the indometacin, an inhibitor of PGE2, they observed an increase in PBMCs proliferation, the same behavior found when the PBMCs are not cocultured with MSCs. More specifically, it was noted the increase in TNF- $\alpha$ and IFN- $\gamma$ from the activated DCs and $\mathrm{T}$ cells when the coculture with MSCs received PGE2 inhibitors. This gives an indication of which PGE2 is a candidate molecule capable of influencing many immunomodulators aspects. This finding is further reinforced with MSCs enhancement of PGE2 production when incubated with the proinflammatory recombinant cytokines TNF- $\alpha$ or IFN- $\gamma$, indicating a negative feedback stimulated by these cytokines.

Chan et al. [139] observed that the MSCs have APC (antigen-presenting cells) characteristic. In APC test, MSCs challenged with C. albicans and T. toxoid were cocultivated with activated CD4+ cells. As time went by, an increased IFN$\gamma$ concentration was observed. The authors found that the MHC II molecule has its expression decreased when the cells are in the presence of high concentrations of IFN- $\gamma$, while expression remains unchanged at low concentrations. Along with the increase in the IFN- $\gamma$ concentration, a decrease in the CD4+ cells proliferation was observed. The question posed is how could MSCs act as APCs in a microenvironment of immune responses when IFN- $\gamma$ levels are expected to be elevated? The authors proposed that MSCs possess the characteristic of PCA at a time limited to a period before the inflammatory response, where the concentration of IFN- $\gamma$ is low. Locking the IFN- $\gamma$ receptor (IFN $\gamma$ RI) using an antiIFN $\gamma$ RI antibody, there was no expression of MHC II. At the same time, it was shown the need of the IFN $\gamma \mathrm{RI}$ activation to induce APC function in MSCs, where the MSCs treated with one control isotype played the role of APC increasing CD4+ cells proliferation and MSCs treated with anti-IFN $\gamma$ RI did not promote the CD4+ cells proliferation. Since the expression of MHC II depends on the IFNgRI activation by IFN$\gamma$, the MSCs' APC role is only possible moments before the IFN- $\gamma$ levels increase during the immune process and once raised, the MSCs modulate to an anti-inflammatory function $[140,141]$. Ryan et al. [142] reported that MSCs stimulated with IFN- $\gamma$ increased the HGF and TGF- $\beta 1$ production without changing the levels of IL-10. Human IL-10, TGF- $\beta 1$, and HGF are known to have immunomodulatory properties. These cytokines have shown to reduce the proliferation of PBMCs in MLC test. Another molecule that suppresses the proliferation of PBMCs by MSCs stimulated with IFN- $\gamma$ is the indoleamine 2,3, dioxygenase (IDO), which occurs via the accumulation of kynurenine, a metabolite of tryptophan [142].

The immunomodulatory capacity of MSCs is not only in the suppression of cell proliferation caused by an immune reaction, it extends to the change of cell types linked to anti-inflammatory processes. The cocultivation of MSCs with CD4+ cells, resulted in a CD25 and FoxP3 increased expression, molecules that characterize Treg cells. The soluble factors such as IL-10, TGF- $\beta 1$, and PGE2 alone did not promote the increase of positive cells for the markers mentioned in culture of CD4+ cells alone. However, cultures of PBMCs that received these molecules showed an increase in the CD25 and FoxP3 expression, without the presence of MSCs, indicating that probably other cells of the immune system aided in induction of Tregs. The cocultivation of MSCs with CD4+ cells in the presence of TGF- $\beta$ and PGE2 inhibitors has decreased the expression of FoxP3 and CD25 proteins on $\mathrm{CD} 4+$. This indicates that the cell-cell contact and these factors are required to induce Tregs by MSCs [143].

Aggarwal and Pittenger [136] proposed a model of MSCs interaction with various immune cells and suggested that the MSCs inhibit or limit the inflammatory response, besides promoting mitigating paths and anti-inflammatory effect. When the MSCs are present in an inflammatory environment created artificially (in vitro), they change the immune response by inhibiting DC1 inflammatory signaling (decreasing IL-12 and TNF- $\alpha$ secretion) and promoting DC2 anti-inflammatory signaling (increasing the secretion of IL-10). Furthermore, when the immature effector T cells are present, the MSCs may interact with and inhibit the development of TH1 and NK signaling (decreasing the secretion of INF- $\gamma$ ) and promoting $\mathrm{TH} 2$ anti-inflammatory signaling and Treg suppressive effect (increasing IL4 secretion). Yagi et al. [144] proposed a model for the interactions of cytokines which MSC express MHC-II and function as 
APCs, at low levels of IFN- $\gamma$. At high levels of IFN- $\gamma$, MHC-II is downregulated MHC-II and B7-H1 is upregulated. IFN- $\gamma$ and TNF- $\alpha$ individually stimulate MSCs to upregulate PGE2, COX-2, and/or IDO. These mediators can inhibit function of immune cells such as T cell, NK cell, and DC.

Other sources of stem cells have the immunomodulator aspect have been investigated. Pierdomenico et al. [145] compared MSCs with dental pulp stem cells (DPSCs) in their immunosuppressive capacity. The authors found that the DPSCs are more immunomodulatory than MSCs. Stem cells from human exfoliated deciduous teeth (SHEDs) are also shown to be more efficient in inhibiting the proliferation of Th17 cells than MSCs [146].

The inhibitory effect of the MSCs over the MLC is not dependent on the origin of the MSCs (autogenous or allogeneic), that can be stated as the most important result of this context $[135,140]$. This immunomodulatory effect remains in those cells even after differentiation, as shown in vitro, by Le Blanc et al. [140]. MSCs which were induced into adipogenesis, chondrogenesis, and osteogenesis did not express class II MHC. The differentiated MSCs continued to inhibit the $\mathrm{T}$ lymphocytes proliferative response, being this feature improved when treated with INF- $\gamma$ [141]. This could show that those cells may be transplanted between patients with different HLA.

As previously observed, apparently, the immunomodulatory property of the stem cells is dependent on the environment in which those are inserted. Seemingly, the stem cells have a homeostatic effect and also possess APC characteristics. During the initial part of an inflammatory process, the MSCs increase their potential of antigen presenting in order to fight infection. However, as time progresses, the proinflammatory environment immunomodulates the MSCs in such a way that those assume an anti-inflammatory character, this feature seems to regulate the whole proinflammatory medium towards homeostasis.

Recently, it has been published a creative strategy of dealing with autoimmune diseases. Zhao et al. [147] applied this strategy directly on type I diabetes patients. These authors developed an apparatus, which enclose nine plates, piled upon each other, where the umbilical cord stem cells (CBSCs) were seeded. The patient's circulatory system was connected to a cell sorter in order to isolate lymphocytes, which after collected were transferred directly to the equipment containing the CB-SCs. After 8- to 10-hour procedure, the lymphocytes were reintroduced into the patient, in a closed circuit. The procedure's result was assessed by measuring the C-peptides levels (a product yielded during the biosynthesis of insulin, which indicates $\beta$-cells functioning). Patients treated have shown increasing levels of C-peptide and reduction in the mean values of glycated hemoglobin $\mathrm{AlC}$ (HbA1C). These results are promising, since the patients who would not have residual function on the $\beta$-cells began to show functional improvement, demonstrated by the glucosestimulated C-peptide levels, even after 40 weeks past the procedure. It was also shown an increase in the Treg cells population and reestablishment of the TH1-, TH2-, and TH3-related cytokines levels. The data indicates that the immune system cells were reprogrammed to recognize the patient's tissue as its own. This statement is reinforced by the evidence that patients with no residual $\beta$-cell function had the metabolism control improved, which indicates reduction on autoimmunity and pancreatic islets recovery.

\section{Conclusion}

Advances in researches aiming for cellular therapy have brought important impacts on the medical field with promises of treatment of many human diseases, and in the biotechnology area with the generation of various products and biomaterials. However, as reported here, it was shown that for cell therapy success and safety, it is necessary to overcome certain limitations, such as the use of animal component in cell cultivation, for instance, the fetal bovine serum. Choosing the stem cells that will be used in cellular therapy is also very important in terms of clinical safety for the patient, since the scientific literature has been reporting the teratogenic potential of embryonic stem cells and iPSCs, and possible adult stem cell lines. In addition to the choice of stem cells, another parameter is the appropriate cell dose for a successful treatment. The cells, most commonly reported in scientific studies, are the haematopoietic origin cells. Based on these reports, we have shown that there is no consensus yet on the amount of stem cells to be transplanted and the patient's body weight. The hematopoietic stem cells are not able to be expanded in vitro, which does not happen with adult stem cells from nonhematopoietic origin, that can be expanded even in low passages in huge quantities, bypassing the current problem of haematopoietic cells that can only be transplanted in individuals with less than $40 \mathrm{~kg}$ on the basis of the quantity of CD34+ progenitors cells. Besides the cellular type and dosage, the proliferation and senescence should be investigated before transplantation because there are reports that chromosomal changes may occur during in vitro cultivation, and such changes could affect the cells engraftment. Therefore, the genomic stability must be considered by conducting karyotype analysis to ensure stability and normality at the occasion of transplantation, although other factors such as miRNA and chromatin changing are a challenge for the future. The use of cells which show immunosuppressive and anti-inflammatory activities is also interesting for cellular therapy, since they overcome the current compatibility problem between individuals and may reinforce the therapeutic success. Summarizing, cell therapy safety and success are bound to be achieved by the characterization of stem cells before those critical issues.

\section{Conflict of Interests}

The authors certify that they have no commercial or associative interest that represents a conflict of interests in connection with the paper.

\section{Acknowledgments}

This work was supported by São Paulo Research Foundation (FAPESP) fellowship programs Processes no. 2010/09491-9 
(Honors Doctorate) and 2009/00510-3 (Young Investigators Awards), and FAPESP Grant 2007/59667-3.

\section{References}

[1] J. van der Valk, D. Brunner, K. De Smet et al., "Optimization of chemically defined cell culture media-Replacing fetal bovine serum in mammalian in vitro methods," Toxicology in Vitro, vol. 24, no. 4, pp. 1053-1063, 2010.

[2] M. J. Martin, A. Muotri, F. Gage, and A. Varki, "Human embryonic stem cells express an immunogenic nonhuman sialic acid," Nature Medicine, vol. 11, no. 2, pp. 228-232, 2005.

[3] M. Sundin, O. Ringdén, B. Sundberg, S. Nava, C. Götherström, and K. Le Blanc, "No alloantibodies against mesenchymal stromal cells, but presence of anti-fetal calf serum antibodies, after transplantation in allogeneic hematopoietic stem cell recipients," Haematologica, vol. 92, no. 9, pp. 1208-1215, 2007.

[4] H. A. El-Enshasy, A. Abdeen, S. H. Abdeen, E. A. ElSayed, and M. El-Demellawy, "Serum concentration effects on the kinetics and metabolism of HeLa-S3 cell growth and cell adaptability for successful proliferation in serum free medium," World Applied Sciences Journal, vol. 6, pp. 608-615, 2009.

[5] H. Zähringer, "Leckerlisfür die Zellen,” Laborjournal, vol. 4, pp. 74-81, 2009.

[6] L. M. Björklund, R. Sánchez-Pernaute, S. Chung et al., "Embryonic stem cells develop into functional dopaminergic neurons after transplantation in a Parkinson rat model," Proceedings of the National Academy of Sciences of the United States of America, vol. 99, no. 4, pp. 2344-2349, 2002.

[7] F. Erdö, C. Bührle, J. Blunk et al., "Host-dependent tumorigenesis of embryonic stem cell transplantation in experimental stroke," Journal of Cerebral Blood Flow and Metabolism, vol. 23, no. 7, pp. 780-785, 2003.

[8] T. Fujikawa, S. H. Oh, L. Pi, H. M. Hatch, T. Shupe, and B. E. Petersen, "Teratoma formation leads to failure of treatment for type I diabetes using embryonic stem cell-derived insulinproducing cells," American Journal of Pathology, vol. 166, no. 6, pp. 1781-1791, 2005.

[9] T. Ishii, K. Yasuchika, T. Machimoto et al., “Transplantation of embryonic stem cell-derived endodermal cells into mice with induced lethal liver damage," Stem Cells, vol. 25, no. 12, pp. 3252-3260, 2007.

[10] E. Kroon, L. A. Martinson, K. Kadoya et al., "Pancreatic endoderm derived from human embryonic stem cells generates glucose-responsive insulin-secreting cells in vivo," Nature Biotechnology, vol. 26, no. 4, pp. 443-452, 2008.

[11] J. Leor, S. Gerecht, S. Cohen et al., "Human embryonic stem cell transplantation to repair the infarcted myocardium," Heart, vol. 93, no. 10, pp. 1278-1284, 2007.

[12] G. Li, R. Luo, J. Zhang et al., "Generating mESC-derived insulin-producing cell lines through an intermediate lineagerestricted progenitor line," Stem Cell Research, vol. 2, no. 1, pp. 41-55, 2009.

[13] N. S. Roy, C. Cleren, S. K. Singh, L. Yang, M. F. Beal, and S. A. Goldman, "Functional engraftment of human ES cell-derived dopaminergic neurons enriched by coculture with telomerase-immortalized midbrain astrocytes," Nature Medicine, vol. 12, no. 11, pp. 1259-1268, 2006.
[14] H. Hentze, P. L. Soong, S. T. Wang, B. W. Phillips, T. C. Putti, and N. R. Dunn, "Teratoma formation by human embryonic stem cells: evaluation of essential parameters for future safety studies," Stem Cell Research, vol. 2, no. 3, pp. 198-210, 2009.

[15] K. Gertow, S. Wolbank, B. Rozell et al., "Organized development from human embryonic stem cells after injection into immunodeficient mice," Stem Cells and Development, vol. 13, no. 4, pp. 421-435, 2004.

[16] P. Stojkovic, M. Lako, R. Stewart et al., "An autogeneic feeder cell system that efficiently supports growth of undifferentiated human embryonic stem cells," Stem Cells, vol. 23, no. 3, pp. 306-314, 2005.

[17] S. A. Przyborski, "Differentiation of human embryonic stem cells after transplantation in immune-deficient mice," Stem Cells, vol. 23, no. 9, pp. 1242-1250, 2005.

[18] B. Blum and N. Benvenisty, "Clonal analysis of human embryonic stem cell differentiation into teratomas," Stem Cells, vol. 25, no. 8, pp. 1924-1930, 2007.

[19] M. J. Cooke, M. Stojkovic, and S. A. Przyborski, "Growth of teratomas derived from human pluripotent stem cells is influenced by the graft site," Stem Cells and Development, vol. 15, no. 2, pp. 254-259, 2006.

[20] M. Amit, V. Margulets, H. Segev et al., "Human feeder layers for human embryonic stem cells," Biology of Reproduction, vol. 68, no. 6, pp. 2150-2156, 2003.

[21] A. B. H. Choo, J. Padmanabhan, A. C. P. Chin, and S. K. W. Oh, "Expansion of pluripotent human embryonic stem cells on human feeders," Biotechnology and Bioengineering, vol. 88, no. 3, pp. 321-331, 2004.

[22] T. W. Plaia, R. Josephson, Y. Liu et al., "Characterization of a new NIH-registered variant human embryonic stem cell line, BG01V: a tool for human embryonic stem cell research," Stem Cells, vol. 24, no. 3, pp. 531-546, 2006.

[23] M. Tzukerman, T. Rosenberg, I. Reiter et al., "The influence of a human embryonic stem cell-derived microenvironment on targeting of human solid tumor xenografts," Cancer Research, vol. 66, no. 7, pp. 3792-3801, 2006.

[24] T. A. Prokhorova, L. M. Harkness, U. Frandsen et al., "Teratoma formation by human embryonic stem cells is site dependent and enhanced by the presence of Matrigel," Stem Cells and Development, vol. 18, no. 1, pp. 47-54, 2009.

[25] O. Brüstle, K. N. Jones, R. D. Learish et al., "Embryonic stem cell-derived glial precursors: a source of myelinating transplants," Science, vol. 285, no. 5428, pp. 754-756, 1999.

[26] S. Arnhold, D. Lenartz, K. Kruttwig et al., "Differentiation of green fluorescent protein-labeled embryonic stem cellderived neural precursor cells into thy-1-positive neurons and glia after transplantation into adult rat striatum," Journal of Neurosurgery, vol. 93, no. 6, pp. 1026-1032, 2000.

[27] B. Soria, E. Roche, G. Berná, T. León-Quinto, J. A. Reig, and F. Martín, "Insulin-secreting cells derived from embryonic stem cells normalize glycemia in streptozotocin-induced diabetic mice," Diabetes, vol. 49, no. 2, pp. 157-162, 2000.

[28] B. E. Reubinoff, P. Itsykson, T. Turetsky et al., "Neural progenitors from human embryonic stem cells," Nature Biotechnology, vol. 19, no. 12, pp. 1134-1140, 2001.

[29] H. Fukuda, J. Takahashi, K. Watanabe et al., "Fluorescenceactivated cell sorting-based purification of embryonic stem cell-derived neural precursors averts tumor formation after transplantation," Stem Cells, vol. 24, no. 3, pp. 763-771, 2006.

[30] S. J. Kattman, T. L. Huber, and G. Keller, "Multipotent Flk-1+ cardiovascular progenitor cells give rise to the cardiomyocyte, endothelial, and vascular smooth muscle lineages," Developmental Cell, vol. 11, no. 5, pp. 723-732, 2006. 
[31] J. Saldeen, V. Kriz, N. Ågren, and M. Welsh, "SHB and angiogenic factors promote ES cell differentiation to insulinproducing cells," Biochemical and Biophysical Research Communications, vol. 344, no. 2, pp. 517-524, 2006.

[32] D. Anderson, T. Self, I. R. Mellor, G. Goh, S. J. Hill, and C. Denning, "Transgenic enrichment of cardiomyocytes from human embryonic stem cells," Molecular Therapy, vol. 15, no. 11, pp. 2027-2036, 2007.

[33] I. Huber, I. Itzhaki, O. Caspi et al., "Identification and selection of cardiomyocytes during human embryonic stem cell differentiation," FASEB Journal, vol. 21, no. 10, pp. 25512563, 2007.

[34] T. Ishii, K. Yasuchika, T. Machimoto et al., “Transplantation of embryonic stem cell-derived endodermal cells into mice with induced lethal liver damage," Stem Cells, vol. 25, no. 12, pp. 3252-3260, 2007.

[35] E. Kroon, L. A. Martinson, K. Kadoya et al., "Pancreatic endoderm derived from human embryonic stem cells generates glucose-responsive insulin-secreting cells in vivo," Nature Biotechnology, vol. 26, no. 4, pp. 443-452, 2008.

[36] J. Leor, S. Gerecht, S. Cohen et al., "Human embryonic stem cell transplantation to repair the infarcted myocardium," Heart, vol. 93, no. 10, pp. 1278-1284, 2007.

[37] G. Li, R. Luo, J. Zhang et al., "Generating mESC-derived insulin-producing cell lines through an intermediate lineagerestricted progenitor line," Stem Cell Research, vol. 2, no. 1, pp. 41-55, 2009.

[38] N. S. Roy, C. Cleren, S. K. Singh, L. Yang, M. F. Beal, and S. A. Goldman, "Functional engraftment of human ES cell-derived dopaminergic neurons enriched by coculture with telomerase-immortalized midbrain astrocytes," Nature Medicine, vol. 12, no. 11, pp. 1259-1268, 2006.

[39] B. Kahan, J. Magliocca, F. Merriam et al., "Elimination of tumorigenic stem cells from differentiated progeny and selection of definitive endoderm reveals a Pdx1+ foregut endoderm stem cell lineage," Stem Cell Research, vol. 6, no. 2, pp. 143-157, 2011.

[40] N. Amariglio, A. Hirshberg, B. W. Scheithauer et al., "Donorderived brain tumor following neural stem cell transplantation in an ataxia telangiectasia patient," PLoS Medicine, vol. 6, no. 2, Article ID e1000029, 2009.

[41] L. Y. Matsuoka, "Graft versus host disease," Journal of the American Academy of Dermatology, vol. 5, no. 5, pp. 595-599, 1981.

[42] M. L. Johnson and E. R. Farmer, "Graft-versus-host reactions in dermatology," Journal of the American Academy of Dermatology, vol. 38, no. 3, pp. 369-392, 1998.

[43] J. A. Hansen, E. W. Petersdorf, M. T. Lin et al., "Genetics of allogeneic hematopoietic cell transplantation. Role of HLA matching, functional variation in immune response genes," Immunologic Research, vol. 41, no. 1, pp. 56-78, 2008.

[44] M. Kyba, R. C. R. Perlingeiro, and G. Q. Daley, "HoxB4 confers definitive lymphoid-myeloid engraftment potential on embryonic stem cell and yolk sac hematopoietic progenitors," Cell, vol. 109, no. 1, pp. 29-37, 2002.

[45] B. P. Sorrentino, "Clinical strategies for expansion of haematopoietic stem cells," Nature Reviews Immunology, vol. 4, no. 11, pp. 878-888, 2004.

[46] A. S. Correia, S. V. Anisimov, J. Y. Li, and P. Brundin, "Stem cell-based therapy for Parkinson's disease," Annals of Medicine, vol. 37, no. 7, pp. 487-498, 2005.

[47] L. Wang, P. Menendez, F. Shojaei et al., "Generation of hematopoietic repopulating cells from human embryonic stem cells independent of ectopic HOXB4 expression,"
Journal of Experimental Medicine, vol. 201, no. 10, pp. 16031614, 2005.

[48] E. M. Horwitz, K. Le Blanc, M. Dominici et al., "Clarification of the nomenclature for MSC: the International Society for Cellular Therapy position statement," Cytotherapy, vol. 7, no. 5, pp. 393-395, 2005.

[49] M. Dominici, K. Le Blanc, I. Mueller et al., "Minimal criteria for defining multipotent mesenchymal stromal cells. The International Society for Cellular Therapy position statement," Cytotherapy, vol. 8, no. 4, pp. 315-317, 2006.

[50] Q. Shang, Z. Wang, W. Liu, Y. Shi, L. Cui, and Y. Cao, "Tissue-engineered bone repair of sheep cranial defects with autologous bone marrow stromal cells," Journal of Craniofacial Surgery, vol. 12, no. 6, pp. 586-593, 2001.

[51] G. Ferrari, G. Cusella-De Angelis, M. Coletta et al., "Muscle regeneration by bone marrow-derived myogenic progenitors," Science, vol. 279, no. 5356, pp. 1528-1530, 1998.

[52] S. Shintani, T. Murohara, H. Ikeda et al., "Mobilization of endothelial progenitor cells in patients with acute myocardial infarction," Circulation, vol. 103, no. 23, pp. 2776-2779, 2001.

[53] W. A. Noort, A. B. Kruisselbrink, P. S. In't Anker et al., "Mesenchymal stem cells promote engraftment of human umbilical cord blood-derived CD34+ cells in NOD/SCID mice," Experimental Hematology, vol. 30, no. 8, pp. 870-878, 2002.

[54] M. Angelopoulou, E. Novelli, J. E. Grove et al., "Cotransplantation of human mesenchymal stem cells enhances human myelopoiesis and megakaryocytopoiesis in NOD/SCID mice," Experimental Hematology, vol. 31, no. 5, pp. 413-420, 2003.

[55] M. Wang, Y. Yang, D. Yang et al., "The immunomodulatory activity of human umbilical cord blood-derived mesenchymal stem cells in vitro," Immunology, vol. 126, no. 2, pp. 220232, 2009.

[56] S. Shintani, T. Murohara, H. Ikeda et al., "Mobilization of endothelial progenitor cells in patients with acute myocardial infarction," Circulation, vol. 103, no. 23, pp. 2776-2779, 2001.

[57] J. Houghton, C. Stoicov, S. Nomura et al., "Gastric cancer originating from bone marrow-derived cells," Science, vol. 306, no. 5701, pp. 1568-1571, 2004.

[58] K. Takahashi and S. Yamanaka, "Induction of pluripotent stem cells from mouse embryonic and adult fibroblast cultures by defined factors," Cell, vol. 126, no. 4, pp. 663-676, 2006.

[59] K. Okita, T. Ichisaka, and S. Yamanaka, "Generation of germline-competent induced pluripotent stem cells," Nature, vol. 448, no. 7151, pp. 313-317, 2007.

[60] D. Duinsbergen, D. Salvatori, M. Eriksson, and H. Mikkers, "Tumors originating from induced pluripotent stem cells and methods for their prevention," Annals of the New York Academy of Sciences, vol. 1176, pp. 197-204, 2009.

[61] H. E. Broxmeyer, E. Gluckman, A. Auerbach et al., "Human umbilical cord blood: a clinically useful source of transplantable hematopoietic stem/progenitor cells," International Journal of Cell Cloning, vol. 8, no. 1, pp. 76-91, 1990.

[62] A. M. Brocklebank and R. L. Sparrow, "Enumeration of CD34+ cells in cord blood: a variation on a single-platform flow cytometric method based on the ISHAGE gating strategy," Cytometry, vol. 44, no. 4, pp. 254-261, 2001. 
[63] J. E. Wagner, N. A. Kernan, M. Steinbuch, H. E. Broxmeyer, and E. Gluckman, "Allogeneic sibling umbilical-cord-blood transplantation in children with malignant and non-malignant disease," Lancet, vol. 346, no. 8969, pp. 214-219, 1995.

[64] G. D’Arena, P. Musto, N. Cascavilla, G. Di Giorgio, F. Zendoli, and M. Carotenuto, "Human umbilical cord blood: immunophenotypic heterogeneity of CD34+ hematopoietic progenitor cells," Haematologica, vol. 81, no. 5, pp. 404-409, 1996.

[65] S. Bruno, L. Gammaitoni, M. Gunetti et al., "Different growth factor requirements for the ex vivo amplification of transplantable human cord blood cells in a NOD/SCID mouse model," Journal of Biological Regulators and Homeostatic Agents, vol. 15, no. 1, pp. 38-48, 2001.

[66] J. C. Jaime-Pérez, R. Monreal-Robles, L. N. Rodríguez-Romo, C. Mancías-Guerra, J. L. Herrera-Garza, and D. GómezAlmaguer, "Evaluation of volume and total nucleated cell count as cord blood selection parameters," American Journal of Clinical Pathology, vol. 136, no. 5, pp. 721-726, 2011.

[67] P. Solves, F. Carbonell-Uberos, V. Mirabet, and R. Roig, "CD34+ cell content for selecting umbilical cord blood units for cryopreservation," Transfusion, vol. 47, no. 3, pp. 552$553,2007$.

[68] I. Van Haute, N. Lootens, K. De Buck et al., "Selecting cord blood units for storage by CD34+ cell counts," Transfusion, vol. 45, no. 3, pp. 455-457, 2005.

[69] J. Y. Wu, C. Liao, Z. P. Xu et al., "Banking and transplantation of umbilical cord blood in Guangzhou, China," Cytotherapy, vol. 8, no. 5, pp. 488-497, 2006.

[70] B. Novelo-Garza, A. Limon-Flores, A. Guerra-Marquez et al., "Establishing a cord blood banking and transplantation program in Mexico: a single institution experience," Transfusion, vol. 48, no. 2, pp. 228-236, 2008.

[71] R. H. Jan, S. H. Wen, M. H. Shyr, and B. L. Chiang, "Impact of maternal and neonatal factors on CD34+ cell count, total nucleated cells, and volume of cord blood," Pediatric Transplantation, vol. 12, no. 8, pp. 868-873, 2008.

[72] P. Solves, A. Perales, R. Moraga, E. Saucedo, M. Angeles Soler, and J. Monleon, "Maternal, neonatal and collection factors influencing the haematopoietic content of cord blood units," Acta Haematologica, vol. 113, no. 4, pp. 241-246, 2005.

[73] R. Nakagawa, T. Watanabe, Y. Kawano et al., "Analysis of maternal and neonatal factors that influence the nucleated and CD34+ cell yield for cord blood banking," Transfusion, vol. 44, no. 2, pp. 262-267, 2004.

[74] M. J. Laughlin, J. Barker, B. Bambach et al., "Hematopoietic engraftment and survival in adult recipients of umbilicalcord blood from unrelated donors," New England Journal of Medicine, vol. 344, no. 24, pp. 1815-1822, 2001.

[75] G. D. Long, M. Laughlin, B. Madan et al., "Unrelated umbilical cord blood transplantation in adult patients," Biology of Blood and Marrow Transplantation, vol. 9, no. 12, pp. 772-780, 2003.

[76] M. J. Laughlin, M. Eapen, P. Rubinstein et al., "Outcomes after transplantation of cord blood or bone marrow from unrelated donors in adults with leukemia," New England Journal of Medicine, vol. 351, no. 22, pp. 2265-2275, 2004.

[77] V. Rocha, M. Labopin, G. Sanz et al., "Transplants of umbilical-cord blood or bone marrow from unrelated donors in adults with acute leukemia," New England Journal of Medicine, vol. 351, no. 22, pp. 2276-2285, 2004.

[78] S. Takahashi, T. Iseki, J. Ooi et al., "Single-institute comparative analysis of unrelated bone marrow transplantation and cord blood transplantation for adult patients with hematologic malignancies," Blood, vol. 104, no. 12, pp. 38133820, 2004.

[79] S. M. Fruchtman, A. Hurlet, R. Dracker et al., "The successful treatment of severe aplastic anemia with autologous cord blood transplantation," Biology of Blood and Marrow Transplantation, vol. 10, no. 11, pp. 741-742, 2004.

[80] E. Gluckman, V. Rocha, W. Arcese et al., "Factors associated with outcomes of unrelated cord blood transplant: guidelines for donor choice," Experimental Hematology, vol. 32, no. 4, pp. 397-407, 2004.

[81] J. E. Wagner, J. N. Barker, T. E. DeFor et al., “Transplantation of unrelated donor umbilical cord blood in 102 patients with malignant and nonmalignant diseases: influence of CD34 cell dose and HLA disparity on treatment-related mortality and survival," Blood, vol. 100, no. 5, pp. 1611-1618, 2002.

[82] P. Hernigou, A. Poignard, O. Manicom, G. Mathieu, and H. Rourd, "The use of percutaneous autologous bone marrow transplantation in nonunion and avascular necrosis of bone," Journal of Bone and Joint Surgery Series B, vol. 87, no. 7, pp. 896-902, 2005.

[83] E. D. Thomas and R. Storb, "Technique for human marrow grafting," Blood, vol. 36, no. 4, pp. 507-515, 1970.

[84] J. O. Bay, R. Peffault De Latour, O. Tournilhac, B. Choufi, and J. Chassagne, "Hematopoietic growth factors and autologous or allogeneic stem cell transplantation," Bulletin $d u$ Cancer, vol. 93, no. 5, pp. 473-482, 2006.

[85] I. Majolino, A. M. Cavallaro, A. Bacigalupo et al., "Mobilization and collection of PBSC in healthy donors: a retrospective analysis of the Italian Bone Marrow Transplantation Group (GITMO)," Haematologica, vol. 82, no. 1, pp. 47-52, 1997.

[86] G. Kobbe, D. Soehngen, A. Heyll et al., "Large volume leukapheresis maximizes the progenitor cell yield for allogeneic peripheral blood progenitor donation," Journal of Hematotherapy and Stem Cell Research, vol. 6, no. 2, pp. 125131, 1997.

[87] G. Miflin, C. Charley, C. Stainer, S. Anderson, A. Hunter, and N. Russell, "Stem cell mobilization in normal donors for allogeneic transplantation: analysis of safety and factors affecting efficacy," British Journal of Haematology, vol. 95, no. 2, pp. 345-348, 1996.

[88] P. Anderlini, J. Lauppe, D. Przepiorka, D. Seong, R. Champlin, and M. Körbling, "Peripheral blood stem cell apheresis in normal donors: feasibility and yield of second collections," British Journal of Haematology, vol. 96, no. 2, pp. 415-417, 1997.

[89] M. Körbling, D. Przepiorka, Y. O. Huh et al., "Allogeneic blood stem cell transplantation for refractory leukemia and lymphoma: potential advantage of blood over marrow allografts," Blood, vol. 85, no. 6, pp. 1659-1665, 1995.

[90] M. T. Delamain, K. Metze, J. F. C. Marques, A. R. C. Reis, C. A. De Souza, and I. Lorand-Metze, "Optimization of CD34+ collection for autologous transplantation using the evolution of peripheral blood cell counts after mobilization with chemotherapy and G-CSF," Transfusion and Apheresis Science, vol. 34, no. 1, pp. 33-40, 2006.

[91] M. S. Rao and M. P. Mattson, "Stem cells and aging: expanding the possibilities," Mechanisms of Ageing and Development, vol. 122, no. 7, pp. 713-734, 2001.

[92] L. Hayflick, "The limited in vitro lifetime of human diploid cell strains," Experimental Cell Research, vol. 37, no. 3, pp. 614-636, 1965.

[93] B. M. Stanulis-Praeger, "Cellular senescence revisited: a review," Mechanisms of Ageing and Development, vol. 38, no. 1, pp. 1-48, 1987. 
[94] J. Campisi, "Replicative senescence: an old lives' tale?" Cell, vol. 84, no. 4, pp. 497-500, 1996.

[95] W. Piacibello, L. Gammaitoni, and Y. Pignochino, "Proliferative senescence in hematopoietic stem cells during ex-vivo expansion," Folia Histochemica et Cytobiologica, vol. 43, no. 4, pp. 197-202, 2005.

[96] M. P. Granger, W. E. Wright, and J. W. Shay, "Telomerase in cancer and aging," Critical Reviews in Oncology/Hematology, vol. 41, pp. 29-40, 2002.

[97] P. H. Hernigou and F. Beaujean, "La moelleosseuse, uneclédans la compréhension de certaines pathologies: un potential thérapeutiquel'autogreffe de moelle," Revue de Chirurgie Orthopédique, vol. 79, supplement 1, pp. 136-137, 1993.

[98] P. Hernigou and F. Beaujean, "Pseudarthrosis is treated by percutaneous autologous bone marrow graft," Revue de Chirurgie Orthopédique et Réparatrice de l'Appareil Moteur, vol. 83, pp. 495-504, 1997.

[99] P. Hernigou and F. Beaujean, "Bone marrow in patients with pseudarthrosis: a study of progenitor cells by in vitro cloning," Revue de Chirurgie Orthopédique et Réparatrice de l'Appareil Moteur, vol. 83, pp. 33-40, 1997.

[100] P. Hernigou and F. Beaujean, "Abnormalities in the bone marrow of the iliac crest in patients who have osteonecrosis secondary to corticosteroid therapy or alcohol abuse," Journal of Bone and Joint Surgery Series A, vol. 79, no. 7, pp. 10471053, 1997.

[101] P. Hernigou, F. Beaujean, and J. C. Lambotte, "Decrease in the mesenchymal stem-cell pool in the proximal femur in corticosteroid-induced osteonecrosis," Journal of Bone and Joint Surgery Series B, vol. 81, no. 2, pp. 349-355, 1999.

[102] P. Hernigou, F. Bernaudin, P. Reinert, M. Kuentz, and J. P. Vernant, "Bone-marrow transplantation in sickle-cell disease. Effect on osteonecrosis: a case report with a four-year follow-up," Journal of Bone and Joint Surgery Series A, vol. 79, no. 11, pp. 1726-1730, 1997.

[103] P. Hernigou and F. Beaujean, "Autologous bone marrow grafting of avascular necrosis before collapse," The Journal of Bone and Joint Surgery, vol. 79, supplement 2, p. 148, 1997.

[104] P. Hernigou and F. Beaujean, "Treatment of osteonecrosis with autologous bone marrow grafting," Clinical Orthopaedics and Related Research, no. 405, pp. 14-23, 2002.

[105] W. L. Grayson, F. Zhao, B. Bunnell, and T. Ma, "Hypoxia enhances proliferation and tissue formation of human mesenchymal stem cells," Biochemical and Biophysical Research Communications, vol. 358, no. 3, pp. 948-953, 2007.

[106] K. K. Ballen, P. S. Becker, F. M. Stewart, and P. J. Quesenberry, "Manipulation of the stem cell as a target for hematologic malignancies," Seminars in Oncology, vol. 27, no. 5, pp. 512523, 2000.

[107] D. Rubio, J. Garcia-Castro, and M. C. Martín, "Spontaneous human adult stem cell transformation," Cancer Research, vol. 65, no. 11, pp. 3035-3039, 2005.

[108] R. Izadpanah, D. Kaushal, C. Kriedt et al., "Long-term in vitro expansion alters the biology of adult mesenchymal stem cells," Cancer Research, vol. 68, no. 11, pp. 4229-4238, 2008.

[109] W. Wagner, P. Horn, M. Castoldi et al., "Replicative senescence of mesenchymal stem cells: a continuous and organized process," PLoS ONE, vol. 3, no. 5, Article ID e2213, 2008.

[110] M. Miura, Y. Miura, H. M. Padilla-Nash et al., "Accumulated chromosomal instability in murine bone marrow mesenchymal stem cells leads to malignant transformation," Stem Cells, vol. 24, no. 4, pp. 1095-1103, 2006.
[111] S. K. Rehen, M. J. McConnell, D. Kaushal, M. A. Kingsbury, A. H. Yang, and J. Chun, "Chromosomal variation in neurons of the developing and adult mammalian nervous system," Proceedings of the National Academy of Sciences of the United States of America, vol. 98, no. 23, pp. 13361-13366, 2001.

[112] R. Danova-Alt, A. Heider, D. Egger, M. Cross, and R. Alt, "Very small embryonic-like stem cells purified from umbilical cord blood lack stem cell characteristics," PLoS ONE, vol. 7, no. 4, Article ID e34899, 2012.

[113] G. Lepperdinger, R. Brunauer, A. Jamnig, G. Laschober, and M. Kassem, "Controversial issue: is it safe to employ mesenchymal stem cells in cell-based therapies?" Experimental Gerontology, vol. 43, no. 11, pp. 1018-1023, 2008.

[114] M. E. Bernardo, N. Zaffaroni, F. Novara et al., "Human bone marrow-derived mesenchymal stem cells do not undergo transformation after long-term in vitro culture and do not exhibit telomere maintenance mechanisms," Cancer Research, vol. 67, no. 19, pp. 9142-9149, 2007.

[115] R. Sawada, T. Ito, and T. Tsuchiya, "Changes in expression of genes related to cell proliferation in human mesenchymal stem cells during in vitro culture in comparison with cancer cells," Journal of Artificial Organs, vol. 9, no. 3, pp. 179-184, 2006.

[116] D. Rubio, S. Garcia, M. F. Paz et al., "Molecular characterization of spontaneous mesenchymal stem cell transformation," PLoS ONE, vol. 3, no. 1, Article ID e1398, 2008.

[117] Y. Wang, D. I. Huso, J. Harrington et al., "Outgrowth of a transformed cell population derived from normal human BM mesenchymal stem cell culture," Cytotherapy, vol. 7, no. 6, pp. 509-519, 2005.

[118] S. Garcia, M. C. Martín, R. de la Fuente, J. C. Cigudosa, J. Garcia-Castro, and A. Bernad, "Pitfalls in spontaneous in vitro transformation of human mesenchymal stem cells," Experimental Cell Research, vol. 316, no. 9, pp. 1648-1650, 2010.

[119] A. V. Roschke, K. Stover, G. Tonon, A. A. Schäffer, and I. R. Kirsch, "Stable karyotypes in epithelial cancer cell lines despite high rates of ongoing structural and numerical chromosomal instability," Neoplasia, vol. 4, no. 1, pp. 19-31, 2002.

[120] J. S. Draper, H. D. Moore, L. N. Ruban, P. J. Gokhale, and P. W. Andrews, "Culture and characterization of human embryonic stem cells," Stem Cells and Development, vol. 13, no. 4, pp. 325-336, 2004.

[121] J. J. Buzzard, N. M. Gough, J. M. Crook, and A. Colman, "Karyotype of human ES cells during extended culture [3] (multiple letters)," Nature Biotechnology, vol. 22, no. 4, pp. 381-382, 2004.

[122] P. Rebuzzini, T. Neri, G. Mazzini, M. Zuccotti, C. A. Redi, and S. Garagna, "Karyotype analysis of the euploid cell population of a mouse embryonic stem cell line revealed a high incidence of chromosome abnormalities that varied during culture," Cytogenetic and Genome Research, vol. 121, no. 1, pp. 18-24, 2008.

[123] M. D. Nicola, C. Carlo-Stella, M. Magni et al., "Human bone marrow stromal cells suppress T-lymphocyte proliferation induced by cellular or nonspecific mitogenic stimuli," Blood, vol. 99, no. 10, pp. 3838-3843, 2002.

[124] M. Krampera, S. Glennie, J. Dyson et al., "Bone marrow mesenchymal stem cells inhibit the response of naive and memory antigen-specific T cells to their cognate peptide," Blood, vol. 101, no. 9, pp. 3722-3729, 2003.

[125] M. Krampera, L. Cosmi, R. Angeli et al., "Role for interferon$\gamma$ in the immunomodulatory activity of human bone marrow 
mesenchymal stem cells," Stem Cells, vol. 24, no. 2, pp. 386398, 2006.

[126] R. Yañez, M. L. Lamana, J. García-Castro, I. Colmenero, M. Ramírez, and J. A. Bueren, "Adipose tissue-derived mesenchymal stem cells have in vivo immunosuppressive properties applicable for the control of the graft-versus-host disease," Stem Cells, vol. 24, no. 11, pp. 2582-2591, 2006.

[127] M. A. González, E. González-Rey, L. Rico, D. Büscher, and M. Delgado, "Treatment of experimental arthritis by inducing immune tolerance with human adipose-derived mesenchymal stem cells," Arthritis and Rheumatism, vol. 60, no. 4, pp. 1006-1019, 2009.

[128] A. Augello, R. Tasso, S. M. Negrini, R. Cancedda, and G. Pennesi, "Cell therapy using allogeneic bone marrow mesenchymal stem cells prevents tissue damage in collageninduced arthritis," Arthritis and Rheumatism, vol. 56, no. 4, pp. 1175-1186, 2007.

[129] B. Parekkadan, A. W. Tilles, and M. L. Yarmush, "Bone marrow-derived mesenchymal stem cells ameliorate autoimmune enteropathy independently of regulatory T cells," Stem Cells, vol. 26, no. 7, pp. 1913-1919, 2008.

[130] E. Zappia, S. Casazza, E. Pedemonte et al., "Mesenchymal stem cells ameliorate experimental autoimmune encephalomyelitis inducing T-cell anergy," Blood, vol. 106, no. 5, pp. 1755-1761, 2005.

[131] L. Sun, K. Akiyama, H. Zhang et al., "Mesenchymal stem cell transplantation reverses multiorgan dysfunction in systemic lupus erythematosus mice and humans," Stem Cells, vol. 27, no. 6, pp. 1421-1432, 2009.

[132] G. Ding, Y. Liu, W. Wang et al., "Allogeneic periodontal ligament stem cell therapy for periodontitis in swine," Stem Cells, vol. 28, no. 10, pp. 1829-1838, 2010.

[133] N. Wada, D. Menicanin, S. Shi, P. M. Bartold, and S. Gronthos, "Immunomodulatory properties of human periodontal ligament stem cells," Journal of Cellular Physiology, vol. 219, no. 3, pp. 667-676, 2009.

[134] Q. Zhang, S. Shi, Y. Liu et al., "Mesenchymal stem cells derived from human gingiva are capable of immunomodulatory functions and ameliorate inflammation-related tissue destruction in experimental colitis," Journal of Immunology, vol. 183, no. 12, pp. 7787-7798, 2009.

[135] A. Bartholomew, C. Sturgeon, M. Siatskas et al., "Mesenchymal stem cells suppress lymphocyte proliferation in vitro and prolong skin graft survival in vivo," Experimental Hematology, vol. 30, no. 1, pp. 42-48, 2002.

[136] S. Aggarwal and M. F. Pittenger, "Human mesenchymal stem cells modulate allogeneic immune cell responses," Blood, vol. 105, no. 4, pp. 1815-1822, 2005.

[137] I. Rasmusson, O. Ringdén, B. Sundberg, and K. Le Blanc, "Mesenchymal stem cells inhibit the formation of cytotoxic $\mathrm{T}$ lymphocytes, but not activated cytotoxic T lymphocytes or natural killer cells," Transplantation, vol. 76, no. 8, pp. 12081213, 2003.

[138] I. Rasmusson, K. Le Blanc, B. Sundberg, and O. Ringdén, "Mesenchymal stem cells stimulate antibody secretion in human B cells," Scandinavian Journal of Immunology, vol. 65, no. 4, pp. 336-343, 2007.

[139] J. L. Chan, K. C. Tang, A. P. Patel et al., "Antigen-presenting property of mesenchymal stem cells occurs during a narrow window at low levels of interferon- $\gamma$," Blood, vol. 107, no. 12, pp. 4817-4824, 2006.

[140] K. Le Blanc, L. Tammik, B. Sundberg, S. E. Haynesworth, and O. Ringdén, "Mesenchymal stem cells inhibit and stimulate mixed lymphocyte cultures and mitogenic responses independently of the major histocompatibility complex," Scandinavian Journal of Immunology, vol. 57, no. 1, pp. 1120, 2003.

[141] K. Le Blanc, C. Tammik, K. Rosendahl, E. Zetterberg, and O. Ringdén, "HLA expression and immunologic properties of differentiated and undifferentiated mesenchymal stem cells," Experimental Hematology, vol. 31, no. 10, pp. 890-896, 2003.

[142] J. M. Ryan, F. Barry, J. M. Murphy, and B. P. Mahon, "Interferon- $\gamma$ does not break, but promotes the immunosuppressive capacity of adult human mesenchymal stem cells," Clinical and Experimental Immunology, vol. 149, no. 2, pp. 353-363, 2007.

[143] K. English, J. M. Ryan, L. Tobin, M. J. Murphy, F. P. Barry, and B. P. Mahon, "Cell contact, prostaglandin E2 and transforming growth factor beta 1 play non-redundant roles in human mesenchymal stem cell induction of $\mathrm{CD} 4^{+} \mathrm{CD} 25^{\text {High }}$ forkhead box $\mathrm{P}^{+}$regulatory $\mathrm{T}$ cells," Clinical and Experimental Immunology, vol. 156, no. 1, pp. 149-160, 2009.

[144] H. Yagi, A. Soto-Gutierrez, B. Parekkadan et al., "Mesenchymal stem cells: mechanisms of immunomodulation and homing," Cell Transplantation, vol. 19, no. 6-7, pp. 667-679, 2010.

[145] L. Pierdomenico, L. Bonsi, M. Calvitti et al., "Multipotent mesenchymal stem cells with immunosuppressive activity can be easily isolated from dental pulp," Transplantation, vol. 80, no. 6, pp. 836-842, 2005.

[146] T. Yamaza, A. Kentaro, C. Chen et al., "Immunomodulatory properties of stem cells from human exfoliated deciduous teeth," Stem Cell Research and Therapy, vol. 1, no. 1, article 5, 2010.

[147] Y. Zhao, Z. Jiang, T. Zhao et al., "Reversal of type 1 diabetes via islet $\beta$ cell regeneration following immune modulation by cord blood-derived multipotent stem cells," BMC Medicine, vol. 10, article 3, 2012. 

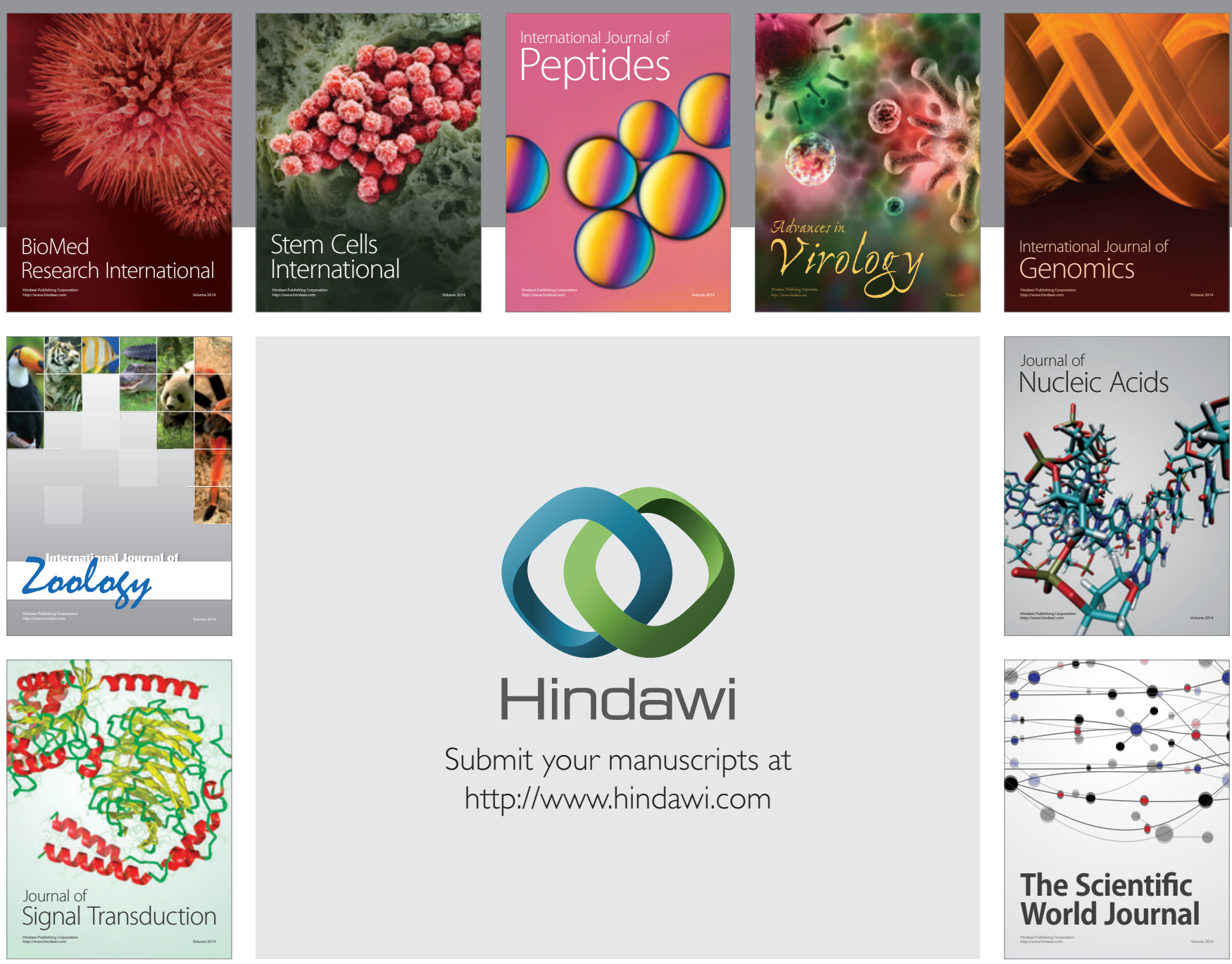

Submit your manuscripts at

http://www.hindawi.com
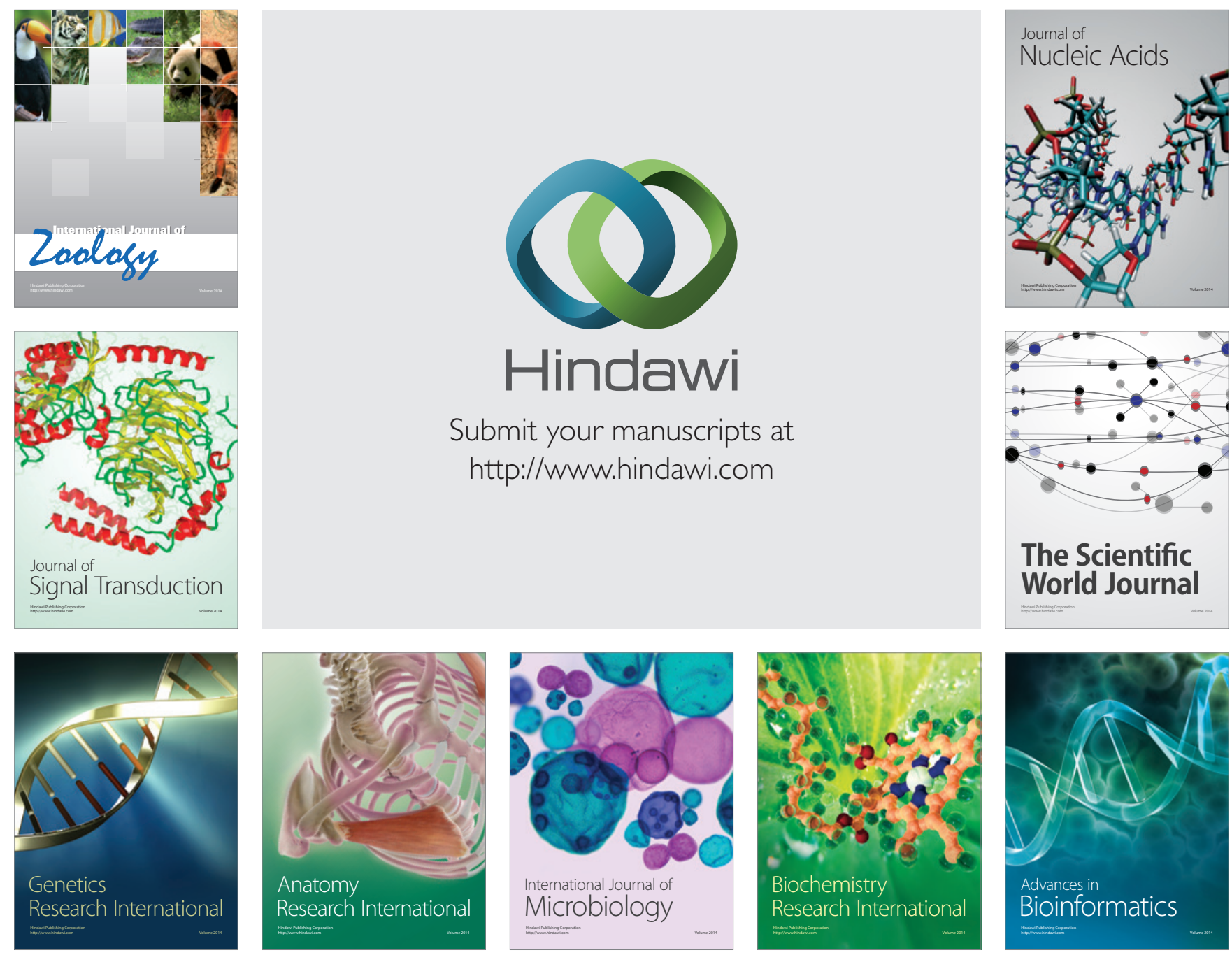

The Scientific World Journal
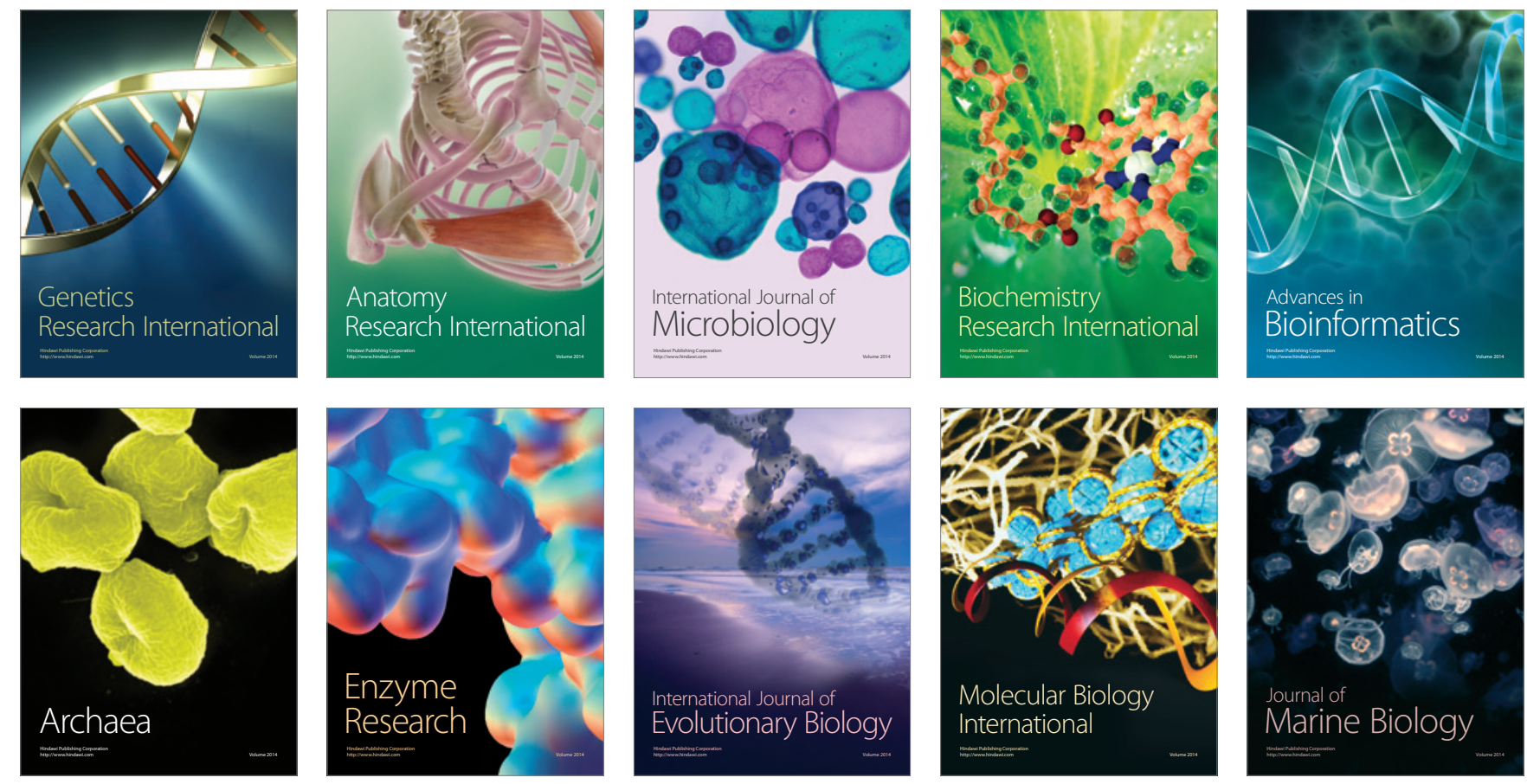